\title{
ANALISIS PENGARUH BENANG WOL DAN LIMBAH BATANG PISANG DALAM RANCANGAN PRODUK KOMPOSIT PEREDAM BUNYI RUANG AKUSTIK
}

\author{
Andri Nasution ${ }^{1}$, Abdul Wahab ${ }^{2,}$ Dimas Nuari $^{3}$ \\ ${ }^{1}$ Dosen Tetap STT Sinar Husni, ihun_mama@yahoo.co.id \\ ${ }^{2}$ Dosen Tidak Tetap STT Sinar Husni, abdulwahab12@yahoo.co.id \\ ${ }^{3}$ Alumni STT Sinar Husni
}

\begin{abstract}
Abstrak
Manusia tidak suka akan kebisingan. Kebisingan didefinisikan sebagai suara yang tidak diinginkan. Teknik pengendalian kebisingan memainkan peranan penting untuk menciptakan suasana lingkungan akustik yang nyaman. Ini dapat tercapai ketika intensitas suara diturunkan ke level yang tidak mengganggu pendengaran manusia. Pencapaian lingkungan akustik yang nyaman ini dapat diperoleh dengan menggunakan beragam teknik. Salah satu teknik tersebut adalah dengan menyerap suara. Akan tetapi penggunaan bahan baku penyerap suara dapat dimodifikasi untuk mengurangi penggunaan bahan yang relatif mahal dan terbatas.

Salah satu ciri dari aktivitas perancangan adalah bahwa selalu dimulai dari akhir dan berakhir di awal. Artinya fokus dari semua aktivitas perancangan adalah titik akhir (deskripsi produk). Salah satu karakteristik manusia adalah mereka selalu berusaha menciptakan sesuatu baik alat maupun benda lainnya untuk membantu kehidupan mereka. Untuk mewujudkan benda tersebut diperlukan suatu rancangan atau desain.

Metode penelitian yang digunakan adalah metode eksperimental yang menguji kemampuan penyerapan bunyi yang dihasilkan dari bahan pelepah pisang dan benang wol dengan berbagai bentuk anyaman yang berbeda dan memilki kemampuan paling optimum dalam meredam bunyi. Penelitian ini nantinya akan menunjukkan bagaimana pengaruh penambahan benang wol dan limbah batang Pisang Kepok terhadap rancangan produk penyerap suara. Sehingga paduan kombinasi wol dan limbah batang Pisang Kepok ini dapat dijadikan sebagai material akustik untuk penanggulangan kebisingan. Hasil penilitian ini menunjukkan peningkatan nilai penyerapan suara dengan kombinasi. Nilai koefisien absorpsi paling baik pada paduan benang wol-limbah batang Pisang Kepok terjadi pada frekuensi menengah dan tinggi.
\end{abstract}

Kata kunci: $\quad$ Tabung impedansi, koefisien serap bunyi, material akustik, benang wol-limbah batang pisang kapok

\section{Pendahuluan}

\subsection{Latar Belakang}

Perkembangan dunia industri sekarang ini, kebutuhan material untuk sebuah produk bertambah. Penggunaan material logam pada berbagai komponen produk semakin berkurang. Hal ini diakibatkan oleh beratnya komponen yang terbuat dari logam, proses pembentukannya yang relatif susah, dapat mengalami korosi dan biaya produksinya mahal. Oleh karena itu, banyak dikembangkan material lain yang mempunyai sifat karakteristik yang sesuai dengan karakteristik material logam yang diinginkan. Salah satu material yang banyak dikembangkan saat ini adalah komposit.

Komposit adalah suatu material yang terbentuk dari kombinasi dua atau lebih material yang mempunyai sifat mekanik lebih kuat dari material pembentuknya. Komposit terdiri dari dua bagian yaitu matrik sebagai pengikat atau pelindung komposit dan filler sebagai pengisi komposit. Serat alam merupakan alternatif filler komposit untuk berbagai komposit polimer karena keunggulannya dibanding serat sintetis. Serat alam mudah didapatkan dengan harga yang murah, mudah diproses, densitasnya rendah, ramah lingkungan, dan dapat diuraikan secara biologi menurut Kusumastuti (2009).

Serat pelepah pisang diperoleh dari pohon pisang kepok (Musa paradisiaca) merupakan serat yang mempunyai sifat mekanik yang baik. Sifat mekanik dari serat batang pisang mempunyai densitas $1,35 \mathrm{gr} / \mathrm{cm}^{3}$, kandungan selulosanya 63 $64 \%$, hemiselulosa 20\%, kandungan lignin 5\%, kekuatan tarik rata-rata $600 \mathrm{Mpa}$, modulus tarik rata-rata $17,85 \mathrm{Gpa}$ dan pertambahan panjang 3,36\% (Lokantara, 2007). Diameter serat pelepah pisang adalah $5,8 \mu \mathrm{m}$, sedangkan panjang seratnya sekitar 30,92 cm - 40,92 cm. Serat wol tumbuh dari kulit domba dan merupakan serat yang relatif kasar dan berkerut dengan sisik pada permukaannya. Serat wol terdiri dari protein. 
Tampilan serat bervariasi tergantung pada jenis domba.

Tabel 1. Sifat Dan Karakteristik Benang Wol

\begin{tabular}{lc}
\hline \multicolumn{1}{c}{ Sifat } & Karakteristik \\
\hline Tampilan Mikroskopis & Berkerut \\
Panjangnya & Sifat Stapel, hingga $40 \mathrm{Cm}$ \\
Warna & Umumnya putih krem \\
Kilauan & Tinggi \\
Kekuatan & Tinggi \\
Elastisitas & Baik \\
Ketahanan & Tinggi \\
Daya serap air & Awalnya cenderung menolak, tapi daya serap baik \\
Panas & Mengeras pada suhu $100^{\circ} \mathrm{C} / 212^{\circ} \mathrm{F}$, terurai pada suhu lebih tinggi \\
Sifat mudah terbakar & Hangus pada suhu $204^{\circ} \mathrm{C} / 400^{\circ} \mathrm{F}$, akan gosong \\
\hline
\end{tabular}

Beberapa penelitian yang berhubungan dengan

komposit serat alam ini adalah, Suwanto (2006) telah mengamati pengaruh temperatur post-curing terhadap kekuatan tarik komposit epoxy resin yang diperkuat dengan anyaman serat pisang. Kekuatan tarik maksimum yang terjadi pada komposit mengalami proses post-curing pada temperatur $1000^{\circ} \mathrm{C}$ sebesar 42,82 $\mathrm{MPa}$, sehingga terjadi peningkatan kekuatan tarik sebesar 40,26\% jika dibandingkan dengan komposit tanpa pemanasan. Kekuatan tarik yang terjadi pada komposit lebih kecil jika dibandingkan dengan kekuatan tarik dua material penyusunnya. Hal ini bisa disebabkan oleh beberapa faktor, yaitu porositas yang cukup tinggi pada komposit, kondisi serat yang kurang seragam, terjadinya delaminasi antara serat dan matriks, dan ikatan permukaan yang rendah antara serat dengan matriks. Berdasarkan latar belakang tersebut, maka dalam penelitian ini, disintesis material komposit dengan pengaruh ketebalan serat batang Pisang Kepok terhadap material komposit poliester-serat alam, dan diharapkan komposit poliester-serat batang pisang dan benang wol lebih baik dari pada poliester murni. Hasil yang biasa dicapai adalah material yang ringan dengan kekuatan tinggi.

\subsection{Tujuan penelitian}

Tujuan penelitian ini ialah untuk mendapatkan rancangan produk yang terbaik dalam pembuatan bahan komposit peredam bunyi yang diperkuat limbah batang Pisang Kepok dan benang wol sebagai bahan pembentuk papan komposit.

\subsection{Rumusan Masalah}

Penelitian ini menganalisis pengaruh benang wol dan limbah batang Pisang Kepok pada proses perancangan produk papan komposit sebagai peredam bunyi. Proses pembuatan bahan ini yang terdiri dari penentuan variasi komposisi antara matriks, limbah batang Pisang Kepok dan benang wol serta resin sebagai pengikat. Sedangkan katalis hanya berfungsi sebagai mempercepat terjadinya proses polimerisasi. Komposisi bahan penyusun direncanakan berdasarkan fraksi berat masing-masing bahan pendukungnya dengan variasi terhadap limbah batang Pisang Kepok dan benang wol serta resin.

\section{Tinjauan Pustaka}

\subsection{Komposit}

Komposit (composite) merupakan kata sifat yang berarti susunan atau gabungan. Composite ini berasal dari kata kerja to composite yang berarti menyusun atau menggabung. Jadi definisi komposit dalam lingkup ilmu material adalah gabungan dua buah material atau lebih yang digabung pada skala makroskopis untuk membentuk material baru yang lebih bermanfaat, ini berbeda dengan alloy (paduan) yang digabung secara mikroskopis. Pada material komposit sifat unsur pendukungnya masih terlihat dengan jelas, sedangkan pada alloy (paduan) sudah tidak kelihatan lagi unsur-unsur pendukungnya. Jenis-jenis material komposit berdasarkan jenis penguatnya dibagi menjadi 3 :

1. Komposit serat, yaitu komposit yang terdiri dari serat dan bahan dasar yang difabrikasi, misalnya serat + resin sebagai perekat.

2. Komposit berlapis (laminated composite), merupakan jenis komposit yang terdiri dari dua lapis atau lebih yang digabungkan menjadi satu dan setiap lapisannya memiliki karakteristik khusus. Contohnya polywood, laminated glass yang sering digunakan 
sebagai bahan bangunan dan kelengkapannya.

3. Komposit partikel (particulate composite), yaitu komposit yang menggunakan partikel atau serbuk sebagai penguatnya dan terdistribusi secara merata dalam matriks. Komposit yang terdiri dari partikel dan matriks seperti butiran (batu dan pasir) yang diperkuat dengan semen yang sering kita jumpai sebagai beton.

\subsubsection{Resin Epoksi}

Resin epoksi atau secara umum dikenal dengan bahan epoksi adalah salah satu dari jenis polimer yang berasal dari kelompok thermoset, yang dibentuk melalui proses polimerisasi kondensasi, bahan plastik yang tidak dapat dilunakkan kembali atau dibentuk kembali kekeadaan sebelum mengalami pengeringan. Proses pembuatannya dapat dilakukan pada suhu kamar dengan memperhatikan zat-zat kimia yang digunakan sebagai pengontrol polimerisasi jaringan silang agar didapatkan hasil yang optimum. Epoksi termasuk kelompok polimer yang digunakan sebagai bahan pelapis, perekat, dan sebagai matriks pada material komposit di beberapa bagian struktural, resin ini juga dipakai sebagai bahan campuran pembuatan kemasan, bahan cetakan, dan perekat. Digunakan juga pada banyak aplikasi seperti automotif, aerospace, perkapalan, dan peralatan elektronik yang secara umum memiliki sifat yang baik dalam hal reaksi kimia, konduktivitas termal, konduktivitas listrik, tahan korosi, kekuatan tarik dan kekuatan bending sangat baik.

Resin epoksi mempunyai sifat-sifat: berstruktur amorf, tidak bisa meleleh, tidak bisa didaur ulang, atom-atomnya berikatan kuat sekali. Keunggulan yang dimiliki resin epoksi ini adalah ketahanannya terhadap panas dan kelembaban, sifat mekanik yang baik, tahan terhadap bahan-bahan kimia, sifat insulator, sifat perekatnya yang baik terhadap berbagai bahan, dan resin ini mudah dalam modifikasi dan pembuatannya. Namun demikian epoksi juga mempunyai kelemahan pada sifat sensitif menyerap air dan getas. Kegunaan epoksi sebagai bahan matriks dibatasi oleh ketangguhan yang rendah dan cenderung rapuh. Oleh sebab itu saat ini terus dilakukan penelitian untuk meningkatkan ketangguhan bahan matriks atau epoksi. Pada beton penggunaan resin epoksi dapat mempercepat proses pengerasan, karena resin epoksi menimbulkan panas sehingga membantu percepatan pengerasan.

\subsubsection{Batang Pisang Kepok}

Tanaman pisang kapok merupakan tanaman dalam golongan terna monokotil tahunan berbentuk pohon yang tersusun atas batang semu. Batang semu ini merupakan tumpukan pelepah daun yang tersusun secara rapat dan teratur. Percabangan tanaman bertipe simpodial dengan meristem ujung memanjang dan membentuk bunga lalu buah. Pucuk lateral (sucker) muncul dari kuncup pada bonggol yang selanjutnya tumbuh menjadi tanaman pisang.

Klasifikasi tanaman pisang kepok menurut Tjitrosoepomo (1991) adalah sebagai berikut:

$\begin{array}{ll}\text { Regnum } & \text { : Plantae } \\ \text { Divisio } & \text { : Spermatophyta } \\ \text { Sub divisi } & \text { : Angiospermae } \\ \text { Classis } & \text { : Monocotyledoneae } \\ \text { Ordo } & \text { : Musales } \\ \text { Familia } & \text { : Musaceae } \\ \text { Genus } & : \text { Musa } \\ \text { Spesies } & \text { : Musa paradisiaca }\end{array}$

\subsubsection{Benang Wol}

Serat wol tumbuh dari kulit domba dan merupakan serat yang relatif kasar dan berkerut dengan sisik pada permukaannya. Serat wol terdiri dari protein. Tampilan serat bervariasi tergantung pada jenis domba. Serat yang lebih halus, lebih lembut dan lebih hangat cenderung memiliki lebih banyak sisik dan lebih halus. Serat yang tebal dan kurang hangat memiliki lebih sedikit sisik dan kasar.

\section{Karakteristik}
a. Tampak berkerut
b. Elastis
c. Higroskopis, mudah menyerap kelembaban


d. Menyatu pada suhu lebih tinggi daripada kapas

e. Tingkat penyebaran api, pelepasan panas dan panas pembakaran lebih rendah

f. Tahan terhadap listrik statis

\section{Aplikasi}
a. Pakaian - jaket, jas, celana, baju hangat, topi dan sebagainya
b. Selimut, karpet, bulu kempa dan pelapis
c. Karpet kuda, kain pelana

\subsection{Teori Gelombang dan Bunyi}

Pada bagian ini akan diberikan beberapa definisi dan pengertian dasar mengenai gelombang dan bunyi serta hal-hal yang berkaitan dengan teori ini.

\subsubsection{Pengertian Gelombang}

Gelombang adalah suatu getaran, gangguan atau energi yang merambat. Dalam hal ini yang merambat adalah getarannya, bukan medium perantaranya. Satu gelombang terdiri dari satu lembah dan satu bukit (untuk gelombang transversal) atau satu renggangan dan satu rapatan (untuk gelombang longitudinal). Besaran-besaran yang digunakan untuk mendiskripsikan gelombang antara lain panjang gelombang $(\lambda)$ adalah jarak antara dua puncak yang berurutan, frekuensi $(f)$ adalah banyaknya gelombang yang melewati suatu titik tiap satuan waktu, periode (T) adalah waktu yang diperlukan oleh gelombang melewati suatu titik, amplitudo (A) adalah simpangan maksimum dari titik setimbang, kecepatan gelombang (v) adalah kecepatan dimana puncak gelombang (atau bagian lain dari gelombang) bergerak.

Kecepatan gelombang harus dibedakan dari kecepatan partikel pada medium itu sendiri. Pada waktu merambat gelombang membawa energi dari satu tempat ke tempat lain. Saat gelombang merambat melalui medium maka energi dipindahkan sebagai energi getaran antar partikel dalam medium tersebut.

\subsubsection{Pengertian Bunyi}

Bunyi secara harafiah dapat diartikan sebagai sesuatu yang kita dengar. Bunyi merupakan hasil getaran dari partikel-partikel yang berada di udara dan energi yang terkandung dalam bunyi dapat meningkat secara cepat dan dapat menempuh jarak yang sangat jauh.

Secara lebih mendetail, Doelle (1972) menyatakan bahwa bunyi mempunyai dua defenisi, yaitu:

1. Secara fisis, bunyi adalah penyimpangan tekanan, pergeseran partikel dalam medium elastik seperti udara. Definisi ini dikenal sebagai bunyi objektif.

2. Secara fisiologis, bunyi adalah sensasi pendengaran yang disebabkan penyimpangan fisis yang digambarkan pada bagian atas. Hal ini disebut sebagai bunyi subjektif.

Secara singkat, Bunyi adalah suatu bentuk gelombang longitudinal yang merambat secara perapatan dan perenggangan terbentuk oleh partikel zat perantara serta ditimbulkan oleh sumber bunyi yang mengalami getaran. Rambatan gelombang bunyi disebabkan oleh lapisan perapatan dan peregangan partikelpartikel udara yang bergerak ke luar, yaitu karena penyimpangan tekanan. Hal serupa juga terjadi pada penyebaran gelombang air pada permukaan suatu kolam dari titik dimana batu dijatuhkan.

Gelombang bunyi adalah gelombang yang dirambatkan sebagai gelombang mekanik longitudinal yang dapat menjalar dalam medium padat, cair dan gas. Medium gelombang bunyi ini adalah molekul yang membentuk bahan medium mekanik. Gelombang bunyi merupakan vibrasi/getaran molekul-molekul zat dan saling beradu satu sama lain namun demikian zat tersebut terkoordinasi menghasilkan gelombang serta mentransmisikan energi bahkan tidak pernah terjadi perpindahan partikel. 


\subsection{Tabung Impedansi}

Ada dua metode standar yang digunakan untuk mengukur koefisien serap bunyi untuk sampel berukuran kecil yaitu menggunakan metode rasio gelombang tegak dan metode transfer fungsi. Kedua metode dirancang untuk pengukuran pada sampel kecil. Metode rasio gelombang tegak mapan, tapi lambat sehingga diganti dengan metode transfer fungsi karena kecepatan dan akurasinya dalam pengukuran.

\subsubsection{Metode Koefisien Absorpsi}

Ada 2 metode untuk koefisien absorpsi, yaitu Metode Perbandingan Gelombang Tegak ISO 105341.dan Metode Transfer Fungsi ISO 10534-2.

\subsubsection{Sifat Akustik}

Kata akustik berasal dari bahasa Yunani yaitu akoustikos, yang artinya segala sesuatu yang bersangkutan dengan pendengaran pada suatu kondisi ruang yang dapat mempengaruhi mutu bunyi. Fenomena absorpsi suara oleh suatu permukaan bahan ditunjukkan pada gambar 2.1

Fenomena suara yang terjadi akibat adanya berkas suara yang bertemu atau menumbuk bidang permukaan bahan, maka suara tersebut akan dipantulkan (reflected), diserap (absorb), dan diteruskan (transmitted) atau ditransmisikan oleh bahan tersebut. Medium gelombang bunyi dapat berupa zat padat, cair, ataupun gas. Frekuensi gelombang bunyi dapat diterima manusia berkisar antara $20 \mathrm{~Hz}$ sampai dengan $20 \mathrm{kHz}$, atau dinamakan sebagai jangkauan yang dapat didengar (audible range).

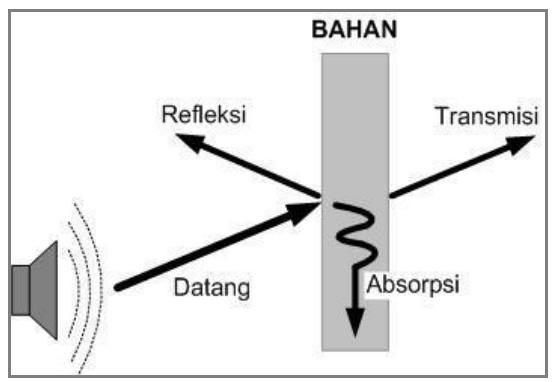

Gambar 1. Fenomena absorpsi suara oleh suatu permukaan bahan.

(Sumber : FTI ITB 2010)

\section{Kerangka Konseptual}

Kerangka konseptual adalah bagaimana penulis menterjemahkan kerangka berpikir dalam melakukan penelitian. Kerangka pemikiran yang melandasi penelitian ini bersumber dari latar belakang permasalahan dan kajian teoritis yang bertujuan untuk membahas dan menjelaskan mengenai pengaruh benang wol dan limbah batang Pisang Kepok pada proses perancangan produk papan komposit sebagai peredam bunyi

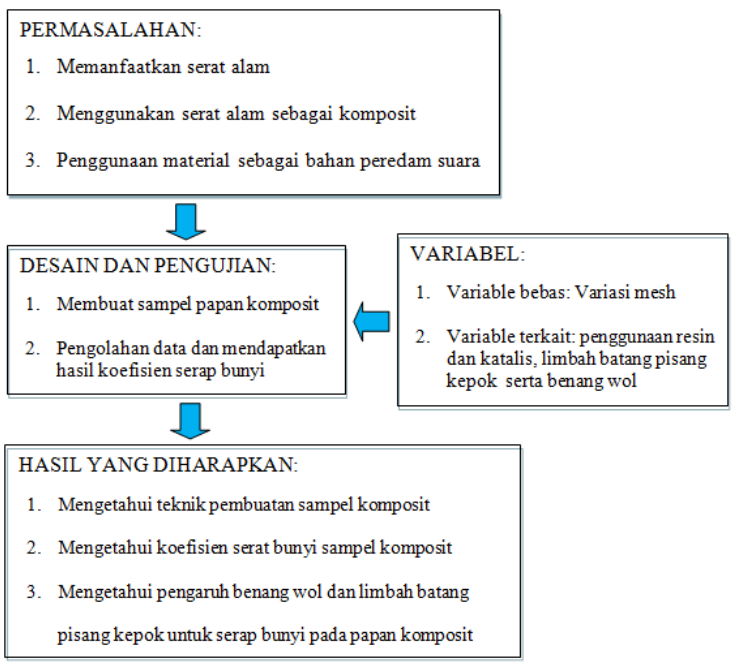

Gambar 2. Kerangka Konseptual Penelitian

\section{Metode Penelitian}

Metode yang digunakan peneliti adalah metode Eksperimental yang menguji kemampuan penyerapan bunyi yang dihasilkan dari bahan pelepah pisang dan benang wol dengan berbagai bentuk anyaman yang berbeda dan memilki kemampuan paling optimum dalam meredam bunyi. Pada penelitian ini peneliti mulai mencari rangkaian tata cara untuk menerangkan suatu kejadian. Mula-mula membuat dugaan-dugaan (hipotesis-hipotesis), kemudian mengumpulkan fakta-fakta kemudian dianalisis dan diolah, hingga akhirnya ditarik kesimpulan. Fakta-fakta tersebut diperoleh dengan eksperimen atau observasi observasi serta dokumen-dokumen. (Narbuko, 2012). 


\subsection{Alat dan Bahan}

Adapun peralatan uji yang di pergunakan selama penelitian ini adalah:

1. Laptop

2. Tabung Impedansi

3. Amplifier

4. Speaker

5. Microphone

6. Microphone Pre-Amplifier

Sedangkan alat yang dipakai untuk proses pembuatan bahan spesimen adalah sebagai berikut:

1. Gelas Ukur

2. Blender

3. Timbangan Digital

4. Mesh Ayakan

5. Cup

6. Bor tangan

7. Kunci Torsi

Adapun bahan spesimen yang digunakan dalam penelitian ini adalah papan komposit berasal dari benang wol dan serat limbah batang Pisang Kepok yang dicapur dengan resin serta katalis dengan cetakan menggunakan pipa paralon berdiameter 101,6 $\mathrm{mm}$ dan dengan ketebalan $5 \mathrm{~mm}$.

\subsection{Prosedur Pengujian}

Prosedur pengujian yang dilakukan adalah sebagai berikut:

1. Siapkan semua peralatan uji dengan diatur sesuai gambar set-up peralatan pengujian.

2. Masukkan spesimen uji dalam tabung impedansi, yaitu ditengah ruang uji dengan posisi tegak lurus terhadap arah ruang tabung.

3. Pengukuran dilakukan pada frekuensi $125 \mathrm{~Hz}$, $250 \mathrm{~Hz}, 500 \mathrm{~Hz}, 1000 \mathrm{~Hz}, 1500 \mathrm{~Hz}$, dan 2000 $\mathrm{Hz}$.

4. Hubungkan mikrofon 1 dan mikrofon 2 pada pre-amp mic channel 1 dan 2. Untuk frekuensi dibawah $228 \mathrm{~Hz}$ yaitu frekuensi $125 \mathrm{~Hz}$ dipakai mikrofon 1' dan 2. Agar lebih jelas dapat dilihat pada gambar 3.21 berikut:

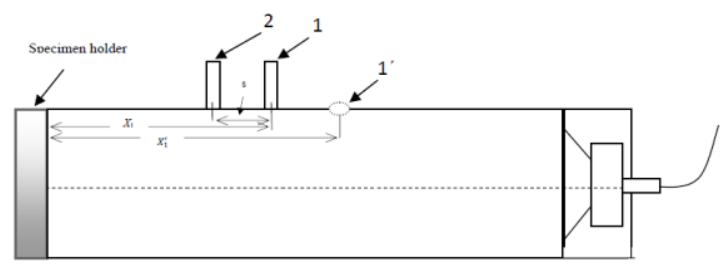

Gambar 3. Posisi mikrofon 2,1 dan 1'

5. Hubungkan output chanel pre-amp mic ke chanel 1 dan chanel 2 pada labjack.

6. Hubungkan Labjack ke port USB pada Laptop lalu buka Software DAQFaqtory untuk menganalisis sinyal.

7. Pada DAQFaqtory buka program Sound Recorder 4ch.

8. Untuk membangkitkan sinyal bunyi, buka program ToneGen. Bunyi yang dikeluarkan berupa pure tone.

9. Atur frekuensi pada ToneGen lalu buka kembali DAQFaqtory untuk melihat grafik tegangan suara pada masing-masing mikrofon.

10. Klik Start/Stop Save untuk Logging data. Data grafik akan otomatis tersimpan dalam drive (D:) pada laptop.

11. Ambil nilai tegangan rata-rata pada masing-masing mikrofon (A dan B) untuk dihitung koefisien absorpsinya dengan bantuan MATLAB.

12. Hitung tekanan suara pada masingmasing mikrofon dengan rumus:

$$
\begin{gathered}
p_{1}=A e^{-j k x_{1}}+B e^{j k x_{1}} \\
p_{2}=A e^{-j k x_{2}}+B e^{-j k x_{2}}
\end{gathered}
$$

13. Hitung faktor Refleksi dan koefisien serap bunyi dengan rumus:

$$
\begin{aligned}
& r=\frac{H_{21}-e^{-j k s}}{e^{j k s}-H_{21}} e^{2 j k x_{1}} \\
& \alpha=1-|r|^{2}
\end{aligned}
$$

14. Ulangi prosedur diatas untuk frekuensi dan sampel yang berbeda.

15. Masukkan data yang telah dihitung ke dalam tabel dan diplot ke dalam bentuk 
grafik agar dapat melihat perbandingan koefisien serap bunyi pada frekuensi yang berbeda dan pada masing-masing sampel.

\section{Analisis Data dan Pembahasan}

Teknik pembuatan sampel spesimen papan komposit berbahan dasar benang wol dan limbah batang pisang kepok, terlebih dahulu batang pisang dipotong-potong dan dijemur hingga kering dengan rendimen 5\% kemudian dihaluskan. Selanjutnya dengan mencampur $100 \mathrm{ml}$ resin (ditambah 5 tetes katalis) serta dimixer $1500 \mathrm{Rpm}$, lalu campurkan 5gr benang wol serta $25 \mathrm{gr}$ batang pisang kepok yang telah dihaluskan. Aduk secara merata resin dan katalis dengan bahan limbah batang Pisang Kepok dan benang wol sehingga menghasilkan papan komposit dengan diameter $0,1016 \mathrm{~m}$ dan ketebalan $0,005 \mathrm{~m}$. penekanan dalam pencetakan sebesar $2 \mathrm{~N} / \mathrm{m}$. Lalu spesimen dibiarkan mengering. Proses pembuatan bahan komposit limbah batang Pisang Kepok dan benang wol menjadi bahan akustik atau peredam suara dapat dilihat pada gambar berikut:
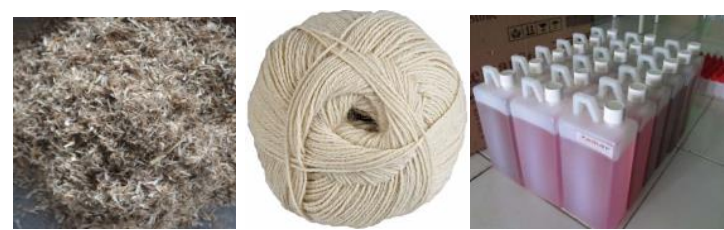

Gambar 4 Bahan sebelum proses pembuatan

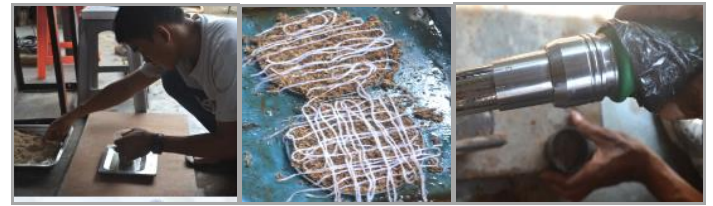

Gambar 5. Melakukan Penimbangan Dan Pengaturan Benang Wol Serta Tekanan

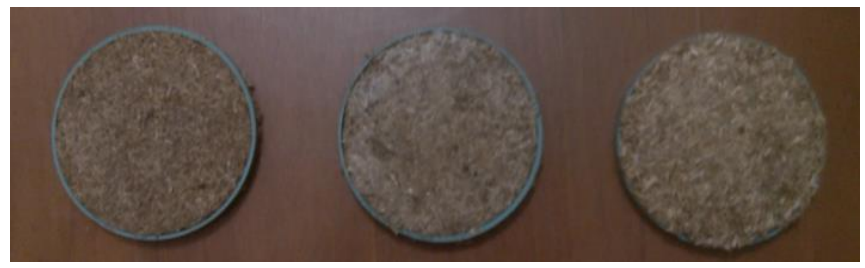

Gambar 6. Bahan Uji Dalam Cetakan
5.1 Hasil Pengujian Pada Spesimen Uji Bahan Halus (mesh 32)

Nilai koefisien absorpsi untuk bahan halus komposit batang Pisang Kepok dan benang Wol dapat dilihat pada tabel 5.1.

Tabel 2. Tabel Koefesien Absorpsi Bahan Halus Komposit Batang Pisang Kepok Dan Benang Wol.

\begin{tabular}{cc}
\hline Frekuensi $(\mathrm{Hz})$ & $\alpha$ \\
\hline 125 & 0.0382 \\
250 & 0.0960 \\
500 & 0.1144 \\
1000 & 0.0615 \\
1500 & 0.1016 \\
2000 & 0.0234 \\
\hline
\end{tabular}

Dalam bentuk grafik koefisien absorpsi dapat dilihat pada gambar 7 .

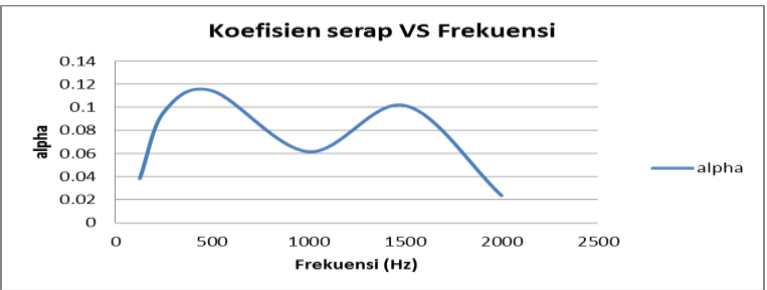

Gambar 7. Grafik Koefesien Absorpsi bahan halus

Gambar 7. menunjukkan grafik hasil pengujian bahan halus komposit batang Pisang Kepok dan benang wol menggunakan metode tabung impedansi dengan sinyal eksitasi berupa pure tone. Untuk material bahan halus komposit batang Pisang Kepok dan benang wol nilai koefisien absorpsi tertinggi yaitu sebesar 0,1144 pada frekuensi $500 \mathrm{~Hz}$. Penyerapan bunyi terendah terjadi pada frekuensi $250 \mathrm{~Hz}$ yaitu sebesar 0,096.

\subsection{Hasil Pengujian Pada Spesimen Uji Bahan Medium (mesh 14)}

Nilai koefisien absorpsi untuk bahan medium komposit batang Pisang Kepok dan benang Wol dapat dilihat pada tabel 3.

Tabel 3. Tabel Koefesien Absorpsi Bahan Medium Komposit Batang Pisang Kepok Dan Benang Wol

\begin{tabular}{cc}
\hline Frekuensi(Hz) & $\alpha$ \\
\hline 125 & 0.0364 \\
\hline
\end{tabular}




\begin{tabular}{cc}
\hline 250 & 0.0076 \\
500 & 0.1949 \\
1000 & 0.2628 \\
1500 & 0.0232 \\
2000 & 0.0371 \\
\hline
\end{tabular}

Dalam bentuk grafik koefisien absorpsi dapat dilihat pada gambar 8 .

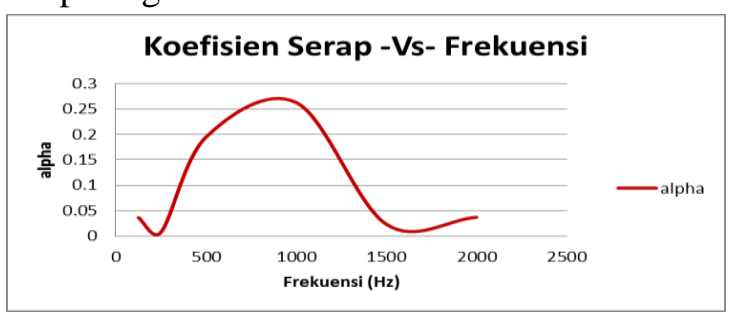

Gambar 8. Grafik Koefesien Absorpsi bahan medium

Gambar 8. menunjukkan grafik hasil pengujian bahan halus komposit batang Pisang Kepok dan benang Wol menggunakan metode tabung impedansi dengan sinyal eksitasi berupa pure tone. Untuk material bahan medium komposit batang Pisang Kepok dan benang Wol nilai koefisien absorpsi tertinggi yaitu sebesar 0,2628 pada frekuensi $1000 \mathrm{~Hz}$. Penyerapan bunyi terendah terjadi pada frekuensi $250 \mathrm{~Hz}$ yaitu sebesar 0,0076 .

\subsection{Hasil Pengujian Pada Spesimen Uji Bahan Kasar (mesh 10) \\ Nilai koefisien absorpsi untuk bahan kasar} komposit batang Pisang Kepok dan benang Wol dapat dilihat pada tabel 4 .

Tabel 4. Tabel Koefesien Absorpsi Bahan Kasar Komposit Batang Pisang Kepok Dan Benang Wol

\begin{tabular}{cc}
\hline Frekuensi(Hz) & A \\
\hline 125 & 0.0364 \\
250 & 0.0282 \\
500 & 0.0493 \\
1000 & 0.1440 \\
1500 & 0.0335 \\
2000 & 0.0234 \\
\hline
\end{tabular}

Dalam bentuk grafik koefisien absorpsi dapat dilihat pada gambar 9 .

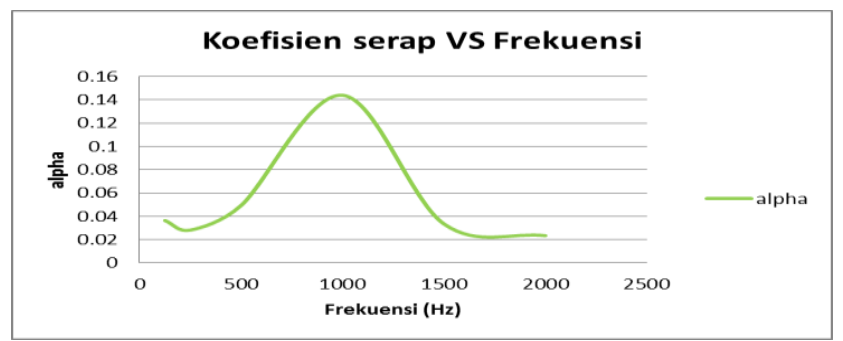

\section{Gambar 9. Grafik Koefesien Absorpsi Bahan Kasar}

Gambar 9. menunjukkan grafik hasil pengujian bahan halus komposit batang Pisang Kepok dan benang wol menggunakan metode tabung impedansi dengan sinyal eksitasi berupa pure tone. Untuk material bahan kasar komposit batang Pisang Kepok dan benang wol nilai koefisien absorpsi tertinggi yaitu sebesar 0,1440 pada frekuensi $1000 \mathrm{~Hz}$. Penyerapan bunyi terendah terjadi pada frekuensi $250 \mathrm{~Hz}$ yaitu sebesar 0,0282 .

Rekapitulasi nilai koefisien absorpsi komposit batang Pisang Kepok dan benang wol bahan halus, medium dan kasar dapat dilihat pada Tabel 5 .

Tabel 5. Tabel Rekapitulasi

\begin{tabular}{|c|c|c|c|}
\hline \multirow{2}{*}{ Frekuensi $(\mathrm{Hz})$} & \multicolumn{3}{|c|}{ alpha $(\alpha)$} \\
\hline & Bahan Halus & Bahan Medium & Bahan Kasar \\
\hline 125 & 0,0382 & 0,0364 & 0,0364 \\
\hline 250 & 0,0960 & 0,0076 & 0,0282 \\
\hline 500 & 0,1144 & 0,1949 & 0,0493 \\
\hline 1000 & 0,0615 & 0,2628 & 0,1440 \\
\hline 1500 & 0,1016 & 0,0232 & 0,0335 \\
\hline 2000 & 0,0234 & 0,0371 & 0,0234 \\
\hline
\end{tabular}

Dalam bentuk grafik rekapitulasi koefisien absorpsi komposit batang Pisang Kepok dan benang wol bahan halus, medium dan kasar dapat dilihat pada gambar 10.

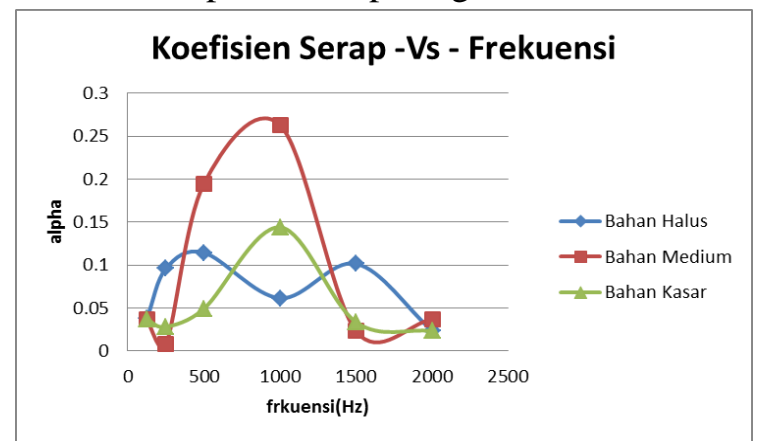

Gambar 10: Grafik rekapitulasi Nilai Koefisien Absorpsi 
Berdasarkan data dan grafik untuk masingmasing bahan, komposit limbah batang Pisang Kepok dan benang wol dengan butiran halus mempunyai koefisien serap tertinggi pada frekuensi $500 \mathrm{~Hz}$ yaitu 0,1144 dan terendah pada frekuensi $2000 \mathrm{~Hz}$ yaitu 0,0234. Komposit batang Pisang Kepok dan benang wol dengan butiran medium koefisien serap tertinggi pada frekuensi $1000 \mathrm{~Hz}$ yaitu 0,2628 dan terendah pada frekuensi $250 \mathrm{~Hz}$ yaitu 0,0076 serta komposit batang Pisang Kepok dan benang wol dengan butiran kasar koefisien serap tertinggi pada frekuensi 1000 $\mathrm{Hz}$ yaitu 0,1440 dan terendah pada frekuensi $2000 \mathrm{~Hz}$ yaitu 0,0234. Sehingga dapat disimpulkan koefisien serap bunyi $(\alpha)$ yang tertinggi adalah bahan batang Pisang Kepok dan benang wol dengan ukuran butir yang medium yaitu 0,2628 pada frekuensi $1000 \mathrm{~Hz}$ dan yang terendah pada bahan medium yaitu 0,0076 pada frekuensi $250 \mathrm{~Hz}$, hal ini sesuai dengan kerapatan dari material batang Pisang Kepok dan benang wol dengan butiran medium mempunyai kerapatan yang tidak terlampau rendah ataupun tinggi.

\section{Kesimpulan dan Saran \\ 6.1 Kesimpulan}

1. Teknik pembuatan sampel spesimen papan komposit berbahan dasar benang wol dan limbah batang pisang kepok, terlebih dahulu batang pisang dipotong-potong dan dijemur hingga kering dengan rendimen 5\% kemudian dihaluskan. Selanjutnya dengan mencampur $100 \mathrm{ml}$ resin (ditambah 5 tetes katalis) serta dimixer 1500 Rpm, lalu campurkan 5gr benang wol serta $25 \mathrm{gr}$ batang pisang kepok yang telah dihaluskan. Aduk secara merata resin dan katalis dengan bahan limbah batang Pisang Kepok dan benang wol sehingga menghasilkan papan komposit dengan diameter $0,1016 \mathrm{~m}$ dan ketebalan $0,005 \mathrm{~m}$. penekanan dalam pencetakan sebesar $2 \mathrm{~N} / \mathrm{m}$. Lalu spesimen dibiarkan mengering.

2. Berdasarkan data dan grafik pada bab 5 Untuk masing-masing bahan, komposit limbah batang Pisang Kepok dan benang wol dengan butiran halus mempunyai koefisien serap tertinggi pada frekuensi $500 \mathrm{~Hz}$ yaitu 0,1144 dan terendah pada frekuensi $2000 \mathrm{~Hz}$ yaitu 0,0234. komposit batang Pisang Kepok dan benang wol dengan butiran medium koefisien serap tertinggi pada frekuensi $1000 \mathrm{~Hz}$ yaitu 0,2628 dan terendah pada frekuensi $250 \mathrm{~Hz}$ yaitu 0,0076 serta komposit batang Pisang Kepok dan benang wol dengan butiran kasar koefisien serap tertinggi pada frekuensi $1000 \mathrm{~Hz}$ yaitu 0,1440 dan terendah pada frekuensi 2000 $\mathrm{Hz}$ yaitu 0,0234. Sehingga dapat disimpulkan koefisien serap bunyi $(\alpha)$ yang tertinggi adalah bahan batang Pisang Kepok dan benang wol dengan ukuran butir yang medium yaitu 0,2628 pada frekuensi $1000 \mathrm{~Hz}$ dan yang terendah pada bahan medium yaitu 0,0076 pada frekuensi 250 $\mathrm{Hz}$, hal ini sesuai dengan kerapatan dari material batang Pisang Kepok dan benang wol dengan butiran medium mempunyai kerapatan yang tidak terlampau rendah ataupun tinggi.

3. Pengaruh benang wol dan batang Pisang Kepok terhadap nilai absorpsi bunyi dengan menggunakan mesh halus akan menghasilkan nilai kerapatan yang tinggi sehingga daya serap rendah, jika menggunakan mesh kasar akan menghasilkan nilai kerapatan yang renggang dan berpori, sedangkan menggunakan mesh medium akan menghasilkan nilai kerapatan yang cukup sehingga menghasilkan daya serap yang cukup tinggi.

\subsection{Saran}

Sebaiknya dalam pembuatan papan komposit untuk serap bunyi tidak menggunakan serat yang terlampau halus ataupun kasar, karena semakin halus serat akan semakin tinggi nilai kerapatannya dan apabila terlampau kasar akan menyebabkan nilai kerapatan yang terlalu renggang atau berpori. 
Penekanan terlampau besar juga akan mengakibatkan kerapatan semakin tinggi.

\section{Daftar Pustaka}

ASTM E1050-98. 2007."Standard Test Method for Impedance and Absorption of Acoustical Materials Using A Tube, Two Microphones and A Digital Frequency Analysis System". American Society for Testing and Materials.

British Standards.2001. "Acoustics - Determination of sound absorption coefficientand impedance in impedance tubes -Part 1: Method using standing wave ratio", BS EN ISO 10534-1.

British Standards.2001. "Acoustics - Determination of sound absorption coefficientand impedance in impedance tubes - Part 2: Transfer Fuction Method", BS EN ISO 10534-2.

Doelle, Leslie L. 1972.Evironment Acoustics.New York: McGraw-Hill Company, Inc.

Kusumastuti, A., 2009, Aplikasi Serat Sisal sebagai Komposit Polimer, Jurusan Teknologi Jasa dan Produksi, Universitas Negeri Semarang, Jurnal Kompetensi Teknik Vol. 1, No. 1, November 200927.

Lokantara, P., 2012, Analisis Kekuatan Impact Komposit Polyester-Serat Tapis Kelapa Dengan Variasi Panjang Dan Fraksi Volume Serat Yang Diberi Perlakuan $\mathrm{NaOH}$, Fakultas Teknik, Universitas Udayana, Kampus Bukit Jimbaran, Bali, Indonesia.

Mubarak, A., 2006, Karakterisasi Sifat Mekanis Material Biokomposit Unidirectional Laminae Serat Heliconia-Resin Poliester, jur. Fisika, FMIPA, IPB.

Suwanto, B., 2006, Pengaruh Temperatur PostCuring terhadap Kekuatan Tarik Komposit Epoksi Resin yang diperkuat Woven Serat Pisang, Jurusan Teknik Sipil Politeknik Negeri Semarang, Semarang.
Tjitrosoepomo, G.. 2000, Morfologi Tumbuhan. Yogyakarta: Gadjah Mada University Press. 